battle unclasped one another, and they went on for several days amicably feeding, burrowing, and building. The same experiment was tried on the carpenter ants, which behead their enemies; their hostile proceedings were not stopped by eau-de-Cologne.

The SNare of the Basilica SPIDER,-Science is under obligations to Mr. McCook of Philadelphia, for his study of the marvellous constructions of the Basilica spider (genus Epeira), near the Colorado River, Texas. It was first found about two feet from the ground upon a bush. The general form is pyramidal, the upper part of it a mass of straight lines knotted and looped, and crossing in all directions. Within this is suspended an open silk dome, of a vast number of radii crossed by regular concentrics. The dome was suspended from the upper erection so as to be perfectly steadied and kept in form. Beneath the dome was a light sheet of irregular cobweb. The spider itself is very beautifully coloured. This form appears to be a capital specimen of transition between the orb-weavers and the line-weavers. It has the characteristics of the line-weavers, namely, right lines and sheet-web in exact detail, and dome-shaped web in outline ; it also has the geometric web of the orb-weavers, or radiating lines regularly crossed by concentrics. An allied species (Epeira globosa) is an orb-weaver, adding to the simple orb an open but distinct tube reaching almost to the centre of the web, with a free ray running along the floor of the tube, kept taut by the fore feet of the spider. An insect struggling in the web communicates the motion directly to the spider, which rushes along the covered gangway to its prey. Sometimes the gangway is imperfect, or even wholly omitted. The orb in the basilica spider appears to be the chief means of capture, the dome the dwelling-place, and the upper pyramid a suspension for this, and a protection against enemies.

Sexual Conditions in the Red Maple.-It is commonly stated that maples bear hermaphrodite, male, and female flowers, but Mr. Thomas Meehan, of Philadelphia, asserts that the red maple is, according to his observations, really diœcious, having only flowers of one sex on the same tree. But the male and female flowers are similar in outward appearance at first opening, except that the small pistil is not developed in the male flowers. The female flowers have anthers of full size, and are supposed to be of both sexes, but the fact is that the anthers do not develop after the flower has opened, and shed no pollen. This is a very remarkable survival from a condition when the flowers were perfect. It is not uncommon to find trees, originally female, sending forth male branches, but Mr. Meehan has not found male trees produce female branches. The male flowers were found fragrant, the female not so.

\section{GEOGRAPHICAL NOTES}

UNDER the title of "Naturalists in the North West," a Sydney paper has recently published some interesting articles, the last of which relates to Mr. Miclucho-Maclay's account of the manners and customs of what he calls the Papuans of the Maclay coast. Their food consists mainly of vegetable products, but they have also some animal food, though it is somewhat scarce. Many of their domestic implements are of a very primitive nature; a flat splint of kangaroo bone forms a knife, of which a large kind is made from a smooth shell; axes are made sometimes of agate, and a few large ones, 3 inches wide, are kept as public property in each village. The dress of these natives is the mal, a piece of cloth prepared like the tapas of the Polynesians, from the bark of trees. 'The men all carry the jambi and the gun, to supply the want of pockets, the former being a bag suspended from the neck, and containing tobacco, \&c., and the latter one woven of different coloured threads, and ornamented with shells.
The gun is slung over the left shoulder, and contains the box of lime, betel-nut, knives, bamboo boxes of red and black dyes, \&c. The natives also wear bracelets of bark or grass above the elbows, into which the dougan is thrust, and implements or weapons are also placed in the bangles on their legs. Wild boar's tusks are highly prized as manly ornaments to be worn on the chest, and ear-rings of tortoise-shell, bamboo, stones, or flowers, are all considered the proper adornment of the men. The women do not decorate themselves to the same extent, but they have cords from the upper part of one ear passing over the forehead to the other, and also bunches of dogs' teeth hanging from the lobes of the ears; they carry two bags, in one of which they place provisions and in the other their young infants or some pet pigs or puppies. Their huts and villages are situated in groups round clearings in the forest, and the plantations are usually at some distance. They have three sorts of houses - for the single people, the families, and a common house, principally used by the bachelors. These habitations do not resemble the pile-dwellings of the Western Papuans, and are only slightly raised above the ground. In each cluster of huts is a gong, like a boat raised on trestles, which, when struck in the right place, emits so great a volume of sound that it can be heard at a distance of six miles. It may be mentioned that these people have no means of obtaining fire, and frequently have to go to the hill tribes, who are acquainted with a cumbersome mode of friction by which they obtain a light.

GrEat exertions are being made by the Marquis de Croizier, and others, to ensure the success of the coming International Congress of Commercial Geography, which will be opened at Paris on September 23, under the presidency of M. Meurand, of the French Foreign Office. Numerous foreign societies have been invited to send representatives to the Congress, and we believe that the Royal Geographical Society will be represented by some members of their Council. The programme of the Congress is an extensive one, the numerous subjects proposed for discussion being arranged under the following five heads: Explorations et Voies Commerciales; Produits Naturels et Manufacturés; Emigration et Colonisation; Enseignement; and Questions Générales. A detailed programme and a résumé of the proceedings of the Congress will be published each day and forwarded to all the members. The meeting will be brought to a close on September 28.

AT a recent meeting of delegates of the German African Society at Berlin, it was resolved to grant the sum of 10,000 marks (500l.) to the International Association for the Exploration of Africa, and also to support Dr. Buchner, who is about to start for a tour through the districts lying south of the Congo River. The reports recently received from Herr Schütte, the engineer of the society, who is now at the Congo, continue to be favourable, and are accompanied by excellent maps of the districts he visits.

DR. OTTO FINSCH, the Director of the Natural History Museum of Bremen, will start for a scientific expedition to Australia at the end of this year; he is sent out by the Royal Academy of Sciences of Berlin, who will defray his expenses from their Humboldt fund.

\section{THE ELASMOTHERIUM}

$A$ MONG the extinct animals of the diluvial age, few A have left such scanty remains as the elasmotherium. At the beginning of the present century Fischer von Weldheim, when examining the palæontological collections of the University of Moscow, came across the half of the under-jawbone of an unknown animal, to which he assigned a place between the rhinoceros and elephant. The name elasmotherium was given to the new species, 
on account of the peculiar appearance of the teeth, which seemed to consist of plates of enamel longitudinally foldect. Later scattered teeth of this animal were found in Hungary, in Sicily, and in various Russian provinces. A few years since a complete under-jawbone was discovered at Petrowski; a fragment of the back part of a skull in the Museum of the Jardin des Plantes, at Paris, which was discovered on the banks of the Rhine in the last century, has likewise lately been identified as

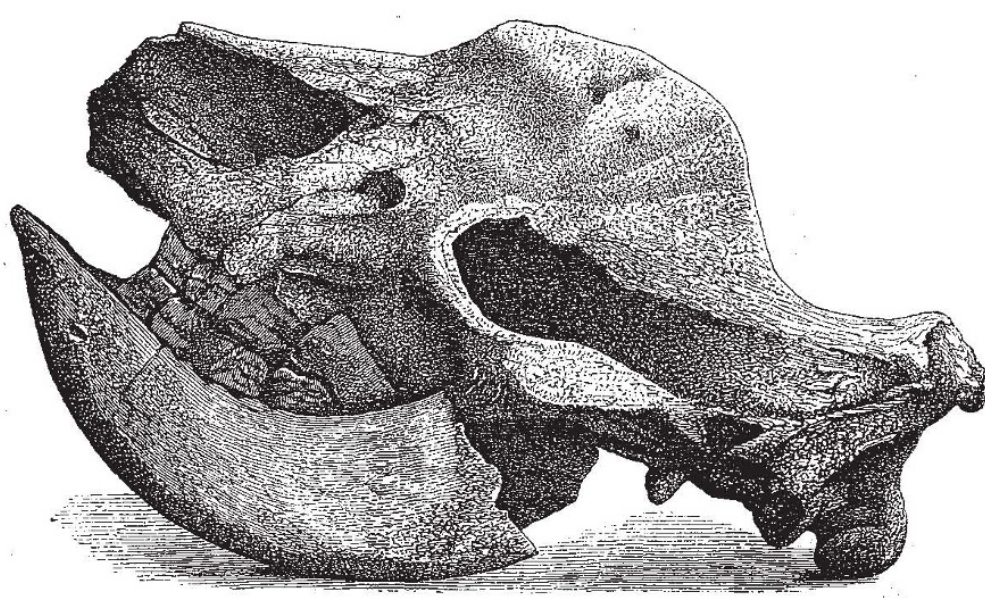

FIG, I,--Side view of the skull of the Elasmotherium

belonging to the elasmotherium. These remains were altogether too limited, to offer the zoologist any satisfactory clue to the general character of this animal. While the form and size of the jaw showed a strong resemblance to that of the rhinoceros, a close relationship was forbidden by the peculiar characteristics of the teeth.

Interesting as were the questions arising with regard to the nature and habits of this extinct resident of Europe, they have hitherto remained unanswered, until a fortunate discovery at the beginning of the present year, placed the zoologist in possession of a well-preserved skull of the elasmotherium. This object, certainly the most valuable of late palaentological discoveries, was found attached to the net of some fishermen in the river Volga, not far from its mouth, a district which has furnished many valuable remains of the extinct fauna of Russia. The St. Petersburg Academy of Sciences has become the fortunate recipient of the newly-found treasure, and to one of its members, Dr. Alexander Brandt, the scientific world owes the first complete summary of the deductions drawn from the study of this skull, as well as its detailed description. Besides his communication on the subject to the Academy, he has published a longer article in the Russian periodical Niwa, and translated it likewise into German.

The skull (Fig. I) itself has the following dimensions. Length 33 inches, height, including the under-jaw, $21 \frac{1}{2}$ inches, breadth $16 \frac{1}{2}$ inches. Its most striking feature is an enormous bony protuberance on the brow. This is hemispherical in shape, possessing a circumference of over 3 feet, and projecting forward about 5 inches, and is hollow, forming a portion of the frontal cavity. Unusual developments of this cavity are noticeable in the skull of the ordinary cow, and more especially in those of the elephant and rhinoceros. As in the case of the latter animal, the protuberance of the skull of the elasmotherium presents a rough, uneven surface, traversed by deep furrows once occupied by blood vessels. The whole analogy with the rhinoceros points with the greatest certainty to the previous existence of a horn, which, to judge from the size of the blood-vessels once encircling the base, must bave possessed enormous dimensions, and easily exceeded the length of the skull itself. The presence of a similar, rough protuberance of much smaller dimensions lower down towards the nostrils, would incline to the supposition that a second smaller horn was likewise present on the elasmotherium.

The front view of the skull bears a general resemblance to that of a horse or a ruminating animal. The rear portion of the skull, however, shows the relationship with the rhinoceros, and this relationship, at least, to the extinct thinoceros, is still more strongly evidenced by the bony partition dividing the nasal cavity, a most peculiar and characteristic anatomical formation ; for with the exception of these two animals, all other mammals known to us possess simply a cartilaginous division in this cavity. The structure of the teeth (Fig. 2) presents, on the contrary, no points of similarity with that of the rhinoceros. They are composed of winding folds of plates of enamel, extending the whole length of the tooth, and presenting, on the upper surface, an odd foliated appearance.

To judge from the skull in question the elasmotherium was most closely allied to the rhinoceros family, standing between it and the horse. Its proportions surpassed, however, those of any of its congeners, thus far known, existing or extinct. The proportions of the skull would point to a length of body ranging between $\mathrm{I} 4$ and 16 feet. With regard to the form of the body and limbs, nothing definite can be said. The nose was much narrower than that of the rhinoceros, while the eyes were larger, and the powers of vision of the elasmotherium, therefore, probably greater than those of the rhinoceros. Analogy with the contemporary rhinoceros and mammoth of

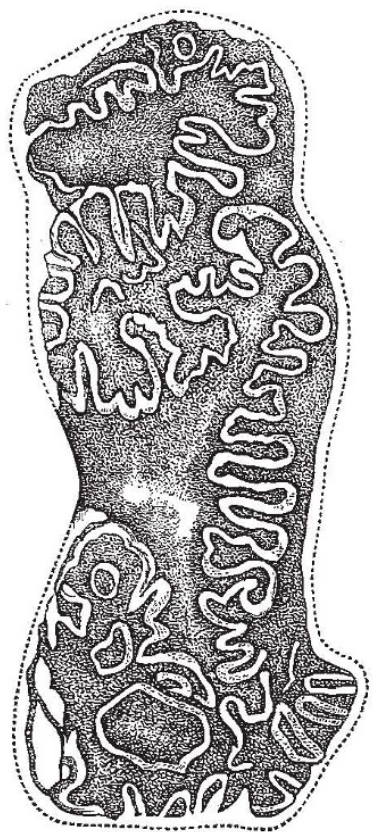

FIG. 2.-Grinciing surface of tooth (natural size).

Siberia would warrant the supposition of the presence of a shaggy coat of hair.

The absolute, as well as the comparative size of the cranial cavity would assign to the elasmotherium a low degree of intelligence. Dr. Brandt pictures it as an 
enormous animal, of great strength, but clumsy, awkward, and slow in its movements. It wallowed in the mud, lazily chewed its food of grass and tender twigs, and stretched itself to rest among the reeds or grass on the river's edge. From this apathetic conclition it would be roused only by the attack of a rival, of a mammotb, of a rbinoceros, or of some one of the great carnivorous animals of that distant epoch. It would then rush enraged on its adversary, and endeavour to lay it low with its formidable horn.

The discoveries of remains of the elasmotherium show that it once wandered over the greater portion of Europe, from the Ural to the Rhine, and as far south as Sicily. It is also highly probable that later palæontological discoveries will show its existence in Asia, in company with the other large mammals, whose remains have been so well preserved in Siberia.

It was also in all probability contemporary with the men of the stone age, its remains occurring in the same deposits, in which the anthropologist finds the flints, collections of bones, and other evidences of prehistoric man. From their weapons the elasmotherium had probably little to fear.

In connection with this interesting discovery $\mathrm{Dr}$. Brandt recounts a tradition of a tribe of Tartars in South Siberia, which describes the death of an enormous black ox. It possessed, however, but a single horn, and that of such size that it could be transported on sledges only. Possibly a reference to the elasmotherium.

\section{UNDERGROUND MONSTERS}

$I^{\mathrm{N}}$ a former number (vol. xvii. p. 325) we gave some account of a curious underground monster, the Minhocao, supposed to exist in Brazil. Dr. Spencer Baird, of the Smithsonian Institution, sends us an interesting document, which shows that the belief in such a monster is not confined to Brazil, but is shared in by the people of Nicaragua. In the Gaceta de Nicaragua for March Io, 1866 , is a long letter signed "Paulino Montenegro," containing a circumstantial account of an object possessing very much the same attributes as the Minhocao. The letter is dated Jinotega, Nicaragua, February 21, 1866. The writer states that he went to Concordia on private business, when he heard on the I7th of a serpent having taken up its abode at a place called La Cuchilla, within the jurisdiction of the village. Along with some friends, M. Montenegro set out on the 18 th to examine in to the foundation of the report. A tradition concerning such a monster has existed from "time immemorial." After having travelled on that day about two leagues (I league $=2.6$ English miles) north-east from the village, they reached the spot where the inhabitants of the neighbourhood had traced signs and tracks, which, M. Montenegro states, positively prove the existence of such an animal.

The most detailed accounts stated that here, some five years before, a sort of platform of about fifty varas diameter had been formed at the foot of a large rock cropping out from a hillside. One of the neighbours had established there an orchard, though no one had been able to account for this new formation. Three years before, however, people began to observe that this little piece of level ground was gradually deepening, and that in the month of November the base of the rock adjoining it became exposed and worn from some agency, notwithstanding that there was not sufficient water to cause the phenomenon. At the same time mighty trees (robles ${ }^{1}$ ) were observed to become uprooted and to fall

x "Roble," in Spanish, means an oak. The same name is found through various parts of Spanish America, applied to trees belonging to very different botanical families, having no natural affinities among each other, and also none to the "Cupuliferæ." On the River Atralo, in New Granada, South America, a huge tree, a species of Tecoma, is called "roble." The name "roble," no doubt, is given to these different forms merely on account of some external resemblance $\mathrm{t}$ ) an or giral Spanish species of cak. in great disorder, while immense rocks were moved and shifted their foundations so much, that in the following month of December, during one night, the road from Chichiguas and Cuchilla to San Rafael del Norte was destroyed by a multitude of cracks and clefts, which had suddenly opened. At that time the ground was observed to be undermined, falling in at intervals. These occurrences were observed some three days before $M$. Montenegro and his friends visited the place, which they saw all to be in accordance with the statements. Immediately on examining the locality for themselves they came to the conclusion that there were signs not of one but of two animals, probably of the shape of huge fishes.

In commencing their work these animals seemed to pursue a kind of an upheaving movement. As the bottom of their hiding-place was loose, shifting ground, the surface of this was seen to give way, while trees were shaken out and came down crashing. The noise of this seemed to scare the animals away. One of them--believed to have been the male on account of its larger size and greater strength-took to the left in descending, but always in a parallel direction with and along the slope of another hill, which here terminated. As it broke through the banks of a ravine, which measured about twenty varas in width and nine feet in depth at its greatest opening, he passed with his head underground. The thrown-up soil showed the tracks of the bead, which left its marks both in the soil and on the roots of the trees, which were broken; the broken pieces being four inches thick. The main part of the body, which certainly must have passed here uncovered, left its traces at the bottom of the ravine. Passing out from this the animal entered upon ground more level and friable, which it went through at a depth of five quarters ( $\mathrm{I}^{*} 25$ varas), forming a furrow and leaving behind a ridge more than one vara high. Following the ravine for a distance of about sixty varas it encountered two deep ditches, when it turned and traced its way back, and, approaching the aforesaid ravine, took to the bed of a pond and disappeared perpendicularly.

The other animal, which left behind a smaller track, and therefore was believed to have been the female, went at once to the right, to the outlet of the pond of water before referred to, leaving behind it everywhere the same marks as the other. When it reached the two deep ditches it turned back also, and undoubtedly encountered its companion afterwards.

The whole ground had become irregularly disturbed and broken up, and the power of these animáls is shown by their being able not only to throw up huge masses of soil but even to move rocks weighing more than thirty quintals.

The animals seem to be covered with a skin clad with scales or plates, the markings of which, imprinted on the soft clay or loam, bear much resemblance to those of the garrobo ${ }^{1}$ in the mud. It appears that the shape of these animals must be like that of the guapote. ${ }^{2}$ The length of the body is at least twelve varas, the height three, and its thickness $\mathrm{x} \cdot 5$ varas.

A tradition about such an animal as this has been kept up unaltered, without contradiction, for more than a hundred years. It is described in general as a large snake, and called "sierpe," on account of its extraordinary size, and living in chaquites. ${ }^{3}$ One is said to have been once killed by lightning the moment it had left its hiding-place in the river "Sebaco viejo."

\section{TWO AUSTRALIAN GEOLOGISTS}

$A$ USTRALIA has recently lost two of its most eminent geologists, the Rev. W. B. Clarke and Mr. Richard Daintree. The death of Mr. Clarke we noted some weeks

I 2 "Garrobo" and "guapote" are names of which the exact application

cannot be ascertained. ciailsm; probably pools or ponds is meant in the present case. 